\title{
Daily Streamflow Trends in Western vs. Eastern Norway and their Attribution to Hydro-Meteorological drivers
}

\author{
Amalie Skålevåg ${ }^{1}$ and K Vormoor ${ }^{1}$ \\ ${ }^{1}$ University of Potsdam
}

February 13, 2021

\begin{abstract}
Climate change in terms of regional warming and modifications in precipitation regimes has large impacts on streamflow in regions where both rainfall and snowmelt are important runoff generating processes like in Norway. Hydrological impacts of recent changes in climate are usually investigated by trend analyses applied on annual, seasonal, or monthly time series. However, neither of them can detect sub-seasonal changes and their underlying causes. Based on high-resolution trend analyses (i.e., applying the Mann-Kendall test on 10-day-moving-averaged daily time series), this study investigated sub-seasonal changes in daily streamflow, rainfall, and snowmelt in 61 and 51 catchments in Western vs. Eastern Norway (Vestlandet vs. Østlandet), respectively, over the period 1983-2012. The relative contribution of rainfall vs. snowmelt to daily streamflow and the changes therein have also been estimated to identify the changing relevance of these driving processes over the same period. Detected changes in daily streamflow were finally attributed to changes in the most important hydro-meteorological drivers using multipleregression models with increasing complexity. Results reveal a coherent picture of earlier spring flow timing in both regions due to earlier snowmelt. Other streamflow trend patterns differ between both regions: Østlandet shows increased summer streamflow in catchments up to $\sim 1100 \mathrm{~m}$ a.s.l. and slightly increased winter streamflow in about $50 \%$ of the catchments, while trend patterns in Vestlandet are less coherent. The importance of rainfall for streamflow contribution has increased in both regions, and the trend attribution reveals that changes in rainfall and snowmelt can explain streamflow changes to some degree in periods and regions where they are dominant (snowmelt: spring and Østlandet; rainfall: autumn and Vestlandet). However, detected streamflow changes can be best explained by adding temperature as an additional predictor which indicates the relevance of additional driving processes for streamflow changes like increased glacier melt and evapotranspiration.
\end{abstract}

\section{Hosted file}

hydroTrends_HYP_manuscript.pdf available at https://authorea.com/users/395401/articles/ 508682-daily-streamflow-trends-in-western-vs-eastern-norway-and-their-attribution-tohydro-meteorological-drivers

\section{Hosted file}

F1_studyarea.eps available at https://authorea.com/users/395401/articles/508682-dailystreamflow-trends-in-western-vs-eastern-norway-and-their-attribution-to-hydrometeorological-drivers 


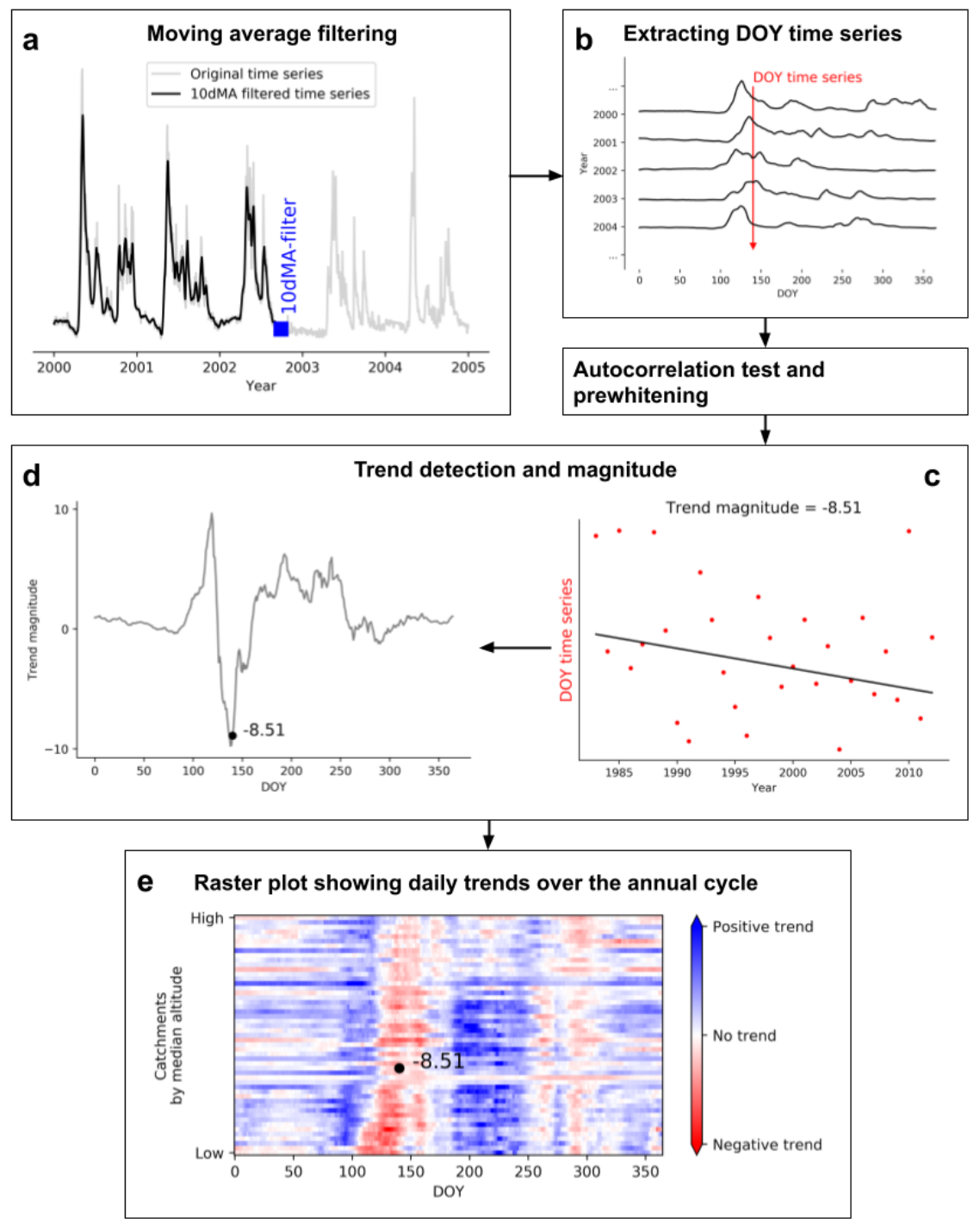

\section{Hosted file}

F3_streamflowTrends.eps available at https://authorea.com/users/395401/articles/508682daily-streamflow-trends-in-western-vs-eastern-norway-and-their-attribution-to-hydrometeorological-drivers

\section{Hosted file}

F4_snowmeltTrends.eps available at https://authorea.com/users/395401/articles/508682daily-streamflow-trends-in-western-vs-eastern-norway-and-their-attribution-to-hydrometeorological-drivers

\section{Hosted file}

F5_rainfallTrends.eps available at https://authorea.com/users/395401/articles/508682daily-streamflow-trends-in-western-vs-eastern-norway-and-their-attribution-to-hydrometeorological-drivers 


\section{Hosted file}

F6_attribution.eps available at https://authorea.com/users/395401/articles/508682daily-streamflow-trends-in-western-vs-eastern-norway-and-their-attribution-to-hydrometeorological-drivers

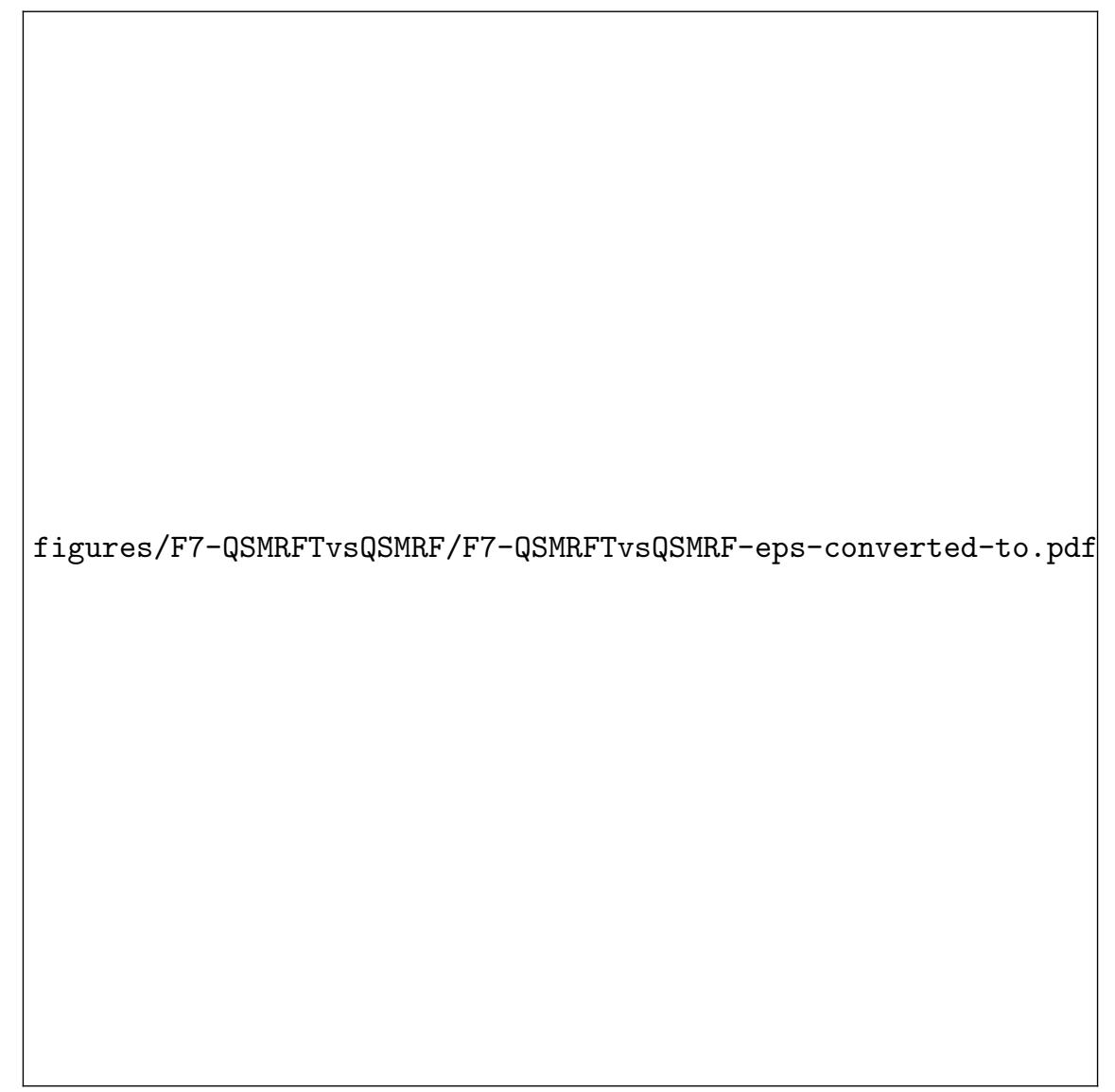

\section{Hosted file}

T1_models.csv available at https://authorea.com/users/395401/articles/508682-dailystreamflow-trends-in-western-vs-eastern-norway-and-their-attribution-to-hydrometeorological-drivers

\section{Hosted file}

T2_overviewAttribution.csv available at https://authorea.com/users/395401/articles/508682daily-streamflow-trends-in-western-vs-eastern-norway-and-their-attribution-to-hydrometeorological-drivers 